\title{
Segregation of Acute Leptin and Insulin Effects in Distinct Populations of Arcuate Proopiomelanocortin Neurons
}

\author{
Kevin W. Williams, ${ }^{1}$ Lisandra 0. Margatho, ${ }^{1}$ Charlotte E. Lee, ${ }^{1}$ Michelle Choi, ${ }^{1}$ Syann Lee, ${ }^{1}$ Michael M. Scott, ${ }^{1}$ \\ Carol F. Elias, ${ }^{1 *}$ and Joel K. Elmquist ${ }^{1,2 *}$ \\ ${ }^{1}$ Division of Hypothalamic Research, Department of Internal Medicine, and ${ }^{2}$ Department of Pharmacology, University of Texas Southwestern Medical \\ Center, Dallas, Texas 75390
}

Acute leptin administration results in a depolarization and concomitant increase in the firing rate of a subpopulation of arcuate proopiomelanocortin (POMC) cells. This rapid activation of POMC cells has been implicated as a cellular correlate of leptin effects on energy balance. In contrast to leptin, insulin inhibits the activity of some POMC neurons. Several studies have described a "cross talk" between leptin and insulin within the mediobasal hypothalamus via the intracellular enzyme, phosphoinositol-3-kinase (PI3K). Interestingly, both insulin and leptin regulate POMC cellular activity by activation of PI3K; however, it is unclear whether leptin and insulin effects are observed in similar or distinct populations of POMC cells. We therefore used dual label immunohistochemistry/in situ hybridization and whole-cell patch-clamp electrophysiology to map insulin and leptin responsive arcuate POMC neurons. Leptin-induced Fos activity within arcuate POMC neurons was localized separate from POMC neurons that express insulin receptor. Moreover, acute responses to leptin and insulin were largely segregated in distinct subpopulations of POMC cells. Collectively, these data suggest that cross talk between leptin and insulin occurs within a network of cells rather than within individual POMC neurons.

\section{Introduction}

The adipose-secreted hormone leptin circulates in the plasma at levels that are proportionate to adipose tissue mass (Zhang et al., 1994; Maffei et al., 1995). Since the proposal of the lipostatic hypothesis by Kennedy (1953) to the targeted molecular disruption of leptin receptors in the brain, a prevalent model of energy homeostasis has developed (Cohen et al., 2001; Balthasar et al., 2004). The model suggests leptin is not only an adipostatic secreted factor, but rather a metabolic cue that communicates directly to the brain the status of available energy stores (Halaas et al., 1995; Ahima et al., 1996; Vaisse et al., 1996; Spiegelman and Flier, 2001; Schwartz and Porte, 2005). Similarly, the $\beta$-cellderived hormone insulin circulates in proportion to blood glucose levels and mediates some of its effects in the CNS (Woods et al., 1979, 1990, 1996; Obici et al., 2002). Despite intense investigation, the cellular and molecular mechanisms regarding how leptin and insulin exert their effects remain to be completely delineated.

Considerable attention has centered on the mediobasal hypothalamus as a key site for the integration of leptin and insulin signaling. The results of these studies suggest that both leptin and

Received June 30, 2009; revised Dec. 1, 2009; accepted Dec. 3, 2009.

This work was supported by National Institutes of Health Grants 1F32DK077487 (to K.W.W.), HD061539 (to C.F.E.), R01DK53301, R01MH61583, and RL1DK081185 (to J.K.E.); by the Coordination of the Advancement of Higher Education/CAPES-Brazil (to L.0.M.), by the Regent's Research Scholar Program award (UTSW, to C.F.E); and by support from 1PL1DK081182, and 1UL1RR024923. We gratefully thank Makoto Fukuda and Jari Rossi for helpful scientific insights and discussions.

${ }^{*}$ C.F.E. and J.K.E. contributed equally to this work.

Correspondence should be addressed to Joel K. Elmquist at the above address. E-mail: joel. elmquist@utsouthwestern.edu.

DOI:10.1523/JNEUROSCI.3118-09.2010

Copyright $\odot 2010$ the authors $\quad 0270-6474 / 10 / 302472-08 \$ 15.00 / 0$ insulin effects on energy homeostasis necessitate the enzyme phosphoinositol-3-kinase (PI3K) (Niswender et al., 2001; Zhao et al., 2002; Rahmouni et al., 2003; Mirshamsi et al., 2004; Carvalheira et al., 2005; Morrison et al., 2005; Morton et al., 2005; Fukuda et al., 2008). Moreover, acute heterogeneous responses of leptin and insulin require $\mathrm{PI} 3 \mathrm{~K}$ in proopiomelanocortin (POMC) neurons of the mediobasal hypothalamic arcuate nucleus (Choudhury et al., 2005; Plum et al., 2006; Hill et al., 2008). It has largely been assumed that these data support both direct and opposing actions of leptin and insulin in arcuate POMC neurons. However, it is unclear how two different hormones share the same signaling cascade but result in opposite effects on cellular activity. Thus, this study was designed to determine how leptin and insulin may acutely interact within POMC cells of the mediobasal hypothalamus.

\section{Materials and Methods}

Subjects. The mice in this study were housed in the University of Texas Southwestern Medical Center Facility. All experiments were performed in accordance with the guidelines established by the National Institute of Health Guide for the Care and Use of Laboratory Animals, as well as with those established by the University of Texas Institutional Animal Care and Use Committee.

Leptin administration. Male (4-16 weeks old) pathogen-free POMCGFP (Parton et al., 2007; Ramadori et al., 2008) mice expressing humanized Renilla green fluorescent protein (hrGFP) under the transcriptional control of the Pomc gene and C57BL6 mice were housed in a light-dark (12 h on/off; lights on at 7:00 A.M.) and temperature-controlled environment with food and water available ad libitum. C57BL6 mice were injected with recombinant murine leptin intraperitoneal $(n=5,5.0$ mg/kg; provided by A. F. Parlow, Harbor-UCLA Medical Center, Torrance, CA; through the National Hormone and Peptide Program) or 
pyrogen-free saline (PFS, $n=3$ ) (Sigma). All injections were given between 11:00 A.M. and 12:00 P.M.

Electrophysiolgy. Whole-cell patch-clamp recordings from POMC neurons maintained in hypothalamic slice preparations and data analysis were performed as previously described (Hill et al., 2008). Briefly, 4- to 16-week-old mice were deeply anesthetized with isoflurane and transcardially perfused with a modified ice-cold artificial CSF (ACSF) (described below), in which an equiosmolar amount of sucrose was substituted for $\mathrm{NaCl}$. The mice were then decapitated, and the entire brain was removed as previously described. After removal, brains were immediately submerged in ice-cold, carbogen-saturated $\left(95 \% \mathrm{O}_{2}\right.$ and $\left.5 \% \mathrm{CO}_{2}\right)$ ACSF (126 mM NaCl, $2.5 \mathrm{~mm} \mathrm{KCl}, 1.2 \mathrm{~mm} \mathrm{MgCl} 2,2.4 \mathrm{~mm} \mathrm{CaCl} 2,1.2 \mathrm{~mm}$ $\mathrm{NaH}_{2} \mathrm{PO}_{4}, 21.4 \mathrm{~mm} \mathrm{NaHCO}$, and $5 \mathrm{~mm}$ glucose). A brain block containing the hypothalamus was made. Coronal sections $(200-250 \mu \mathrm{M})$ were cut with a Leica VT1000S Vibratome and then incubated in oxygenated ACSF at room temperature for at least $1 \mathrm{~h}$ before recording. Slices were transferred to the recording chamber and allowed to equilibrate for $10-20 \mathrm{~min}$ before recording. The slices were bathed in oxygenated ACSF $\left(32^{\circ} \mathrm{C}-34^{\circ} \mathrm{C}\right)$ at a flow rate of $\sim 2 \mathrm{ml} / \mathrm{min}$.

The pipette solution for whole-cell recording was modified to include an intracellular dye (Alexa Fluor 594) for whole-cell recording: 120-130

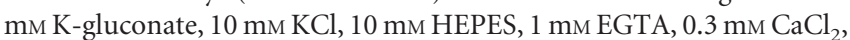
$1 \mathrm{~mm} \mathrm{MgCl} 2,2-5 \mathrm{~mm}(\mathrm{Mg})$-ATP, and $0.3 \mathrm{~mm}(\mathrm{Na})$-GTP, $0.03 \mathrm{~mm}$ Alexa Fluor 594 hydrazide dye, pH 7.3. Epifluorescence was briefly used to target fluorescent cells, at which time the light source was switched to infrared differential interference contrast imaging to obtain the wholecell recording (Zeiss Axioskop FS2 Plus equipped with a fixed stage and a QuantEM:512SC electron-multiplying charge-coupled device camera). Electrophysiological signals were recorded using an Axopatch 700B amplifier (Molecular Devices), low-pass filtered at $2-5 \mathrm{kHz}$, digitized at 88 $\mathrm{kHz}$ (Neuro-corder; Cygnus Technology), stored on videotape, and analyzed offline on a PC with pCLAMP programs (Molecular Devices). Recording electrodes had resistances of 2.5-5 $\mathrm{M} \Omega$ when filled with the $\mathrm{K}$-gluconate internal solution. Input resistance was assessed by measuring voltage deflection at the end of the response to a hyperpolarizing rectangular current pulse ( $400-500 \mathrm{~ms}$ of $-20 \mathrm{pA})$. Membrane potential values were compensated to account for junction potential $(-8 \mathrm{mV})$.

Insulin (50 nM, Humulin-R $100 \mathrm{U} / \mathrm{ml}$; Lilly) and leptin (100 nM; provided by A. F. Parlow, through the National Hormone and Peptide Program) were added to the ACSF for specific experiments. Solutions containing insulin or leptin were typically perfused for 2-4 min. A peptide-induced effect was required to be associated temporally with peptide application, and the response had to be stable within a few minutes. A neuron was considered depolarized or hyperpolarized if a change in membrane potential was at least $2 \mathrm{mV}$ in amplitude. After recording, slices were fixed with $4 \%$ formalin in PBS at $4^{\circ} \mathrm{C}$ overnight. After washing in PBS, slices were mounted onto slides, covered in Vectashield (Vector Laboratories), and coverslipped to reduce photo-oxidation during visualization with fluorescent light. Cells were then visualized with ApoTome imaging system (Imager Z1; Zeiss) to identify post hoc the anatomical location of the recorded neuron.

Insulin receptor probe production. Probes for insulin receptor (insulinR) were derived from PCR fragments amplified with iTaq DNA polymerase (Bio-Rad) from cDNA generated with SuperScript III First-Strand Synthesis System for reverse transcription-PCR (Invitrogen) from total mouse hypothalamic RNA (BD Biosciences). The PCR products were cloned with the TOPO TA Cloning Kit for Sequencing (Invitrogen). The insulinR probe spans nucleotides $2448-$ 28944 of GenBank accession number NM_010568. Antisense- and sense ${ }^{35}$ S-labeled probes were generated with MAXIscript In Vitro Transcription Kits (Ambion) with ${ }^{35} \mathrm{~S}$-UTP. The nucleotide mixture was then digested with DNAase, and the labeled probes were purified and collected by using resin spin columns (GE Healthcare). The ${ }^{35} \mathrm{~S}$ labeled probes were diluted $\left(10^{6} \mathrm{dpm} / \mathrm{ml}\right)$ in a hybridization solution containing 50\% formamide, $10 \mathrm{~mm}$ Tris- $\mathrm{HCl}, \mathrm{pH} 7.5$ (Invitrogen), $1 \%$ sheared salmon sperm DNA (Sigma-Aldrich), $5 \mathrm{mg}$ of tRNA (Invitrogen), 2.5\% total yeast RNA (Sigma), $100 \mathrm{~mm}$ dithiothreitol, $10 \%$ dextran sulfate, $0.6 \mathrm{~m} \mathrm{NaCl}, 0.5 \mathrm{~mm}$ EDTA, pH 8.0, 0.1\% SDS, $0.1 \%$ sodium thiosulphate, and $1 \times$ Denhardt's solution (Sigma). Hybrid-

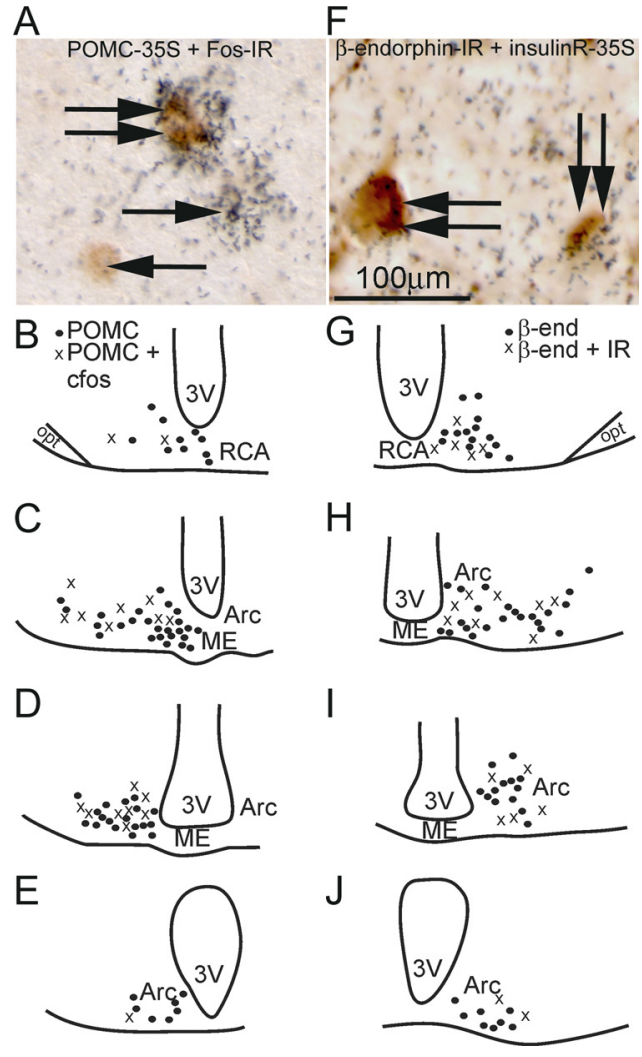

Figure 1. Differential expression of leptin and insulin POMC cells in the retrochiasmatic area and the arcuate nucleus. $\boldsymbol{A}$, Immunohistochemistry coupled with ISHH demonstrates that some POMC neurons express Fos-IR following intraperitoneal leptin. The neurons containing clusters of silver grains were hybridized with ${ }^{35}$ S-labeled POMC riboprobe. The Fos immunoreactive neurons contain brown nuclear reaction product. Single arrows indicate cells positive for POMCISHH or Fos-IR. Double arrows indicate cells positive for both ISHH and immunoreactivity. $\boldsymbol{B}-\boldsymbol{E}$, Line drawings of four rostral to caudal levels of the mouse hypothalamus illustrate the distribution of Fos-IR POMC neurons in the RCA and the Arc. $\boldsymbol{F}$, Immunohistochemistry coupled with ISHH demonstrates that some B-endorphin containing neurons also express insulinR. The neurons containing clusters of silver grains were hybridized with ${ }^{35}$ S-labeled insulinR riboprobe. The B-endorphin immunoreactive neurons contain the brown nuclear reaction product. Double arrows indicate cells positive for both insulinR-ISHH and B endorphin-IR. G-J, Line drawings of four rostral to caudal levels of the mouse hypothalamus demonstrates insulinR expression in B-endorphin neurons in the RCA and the Arc.

ization solution and a coverslip were applied to each slide, and sections were incubated overnight, at $57^{\circ} \mathrm{C}$. On the following day, sections were incubated in $0.002 \%$ RNase A (Roche Applied Bioscience) solution and submitted to stringency washes. Sections were then dehydrated and enclosed in $\mathrm{x}$-ray film cassettes with Kodak BioMax MR-2 film (Carestream Molecular Imaging) for $3 \mathrm{~d}$. Subsequently, the slides were dipped in Kodak NTB autoradiographic emulsion (Carestream Molecular Imaging), dried, and stored at $4^{\circ} \mathrm{C}$ for $15 \mathrm{~d}$. Slides were developed with Dektol developer and Fixer (Kodak/Carestream Molecular Imaging), counterstained with thionin, dehydrated, cleared in xylenes, and coverslipped with Permaslip (Newcomer Supply). Control procedures included hybridization with sense probes and tissue pretreatment with RNAase A $(200 \mu \mathrm{g} /$ $\mathrm{ml}$ ). No specific hybridization was observed following either control procedure.

Dual label immunohistochemistry/in situ hybridization. The procedure was a modification of that described previously (Liu et al., 2003). Tissue was rinsed with DEPC-treated PBS, pH 7.0 for $1 \mathrm{~h}$ and in $0.1 \%$ sodium borohydride (Sigma) in DEPC-PBS for $15 \mathrm{~min}$. Sections were then incubated for $10 \mathrm{~min}$ in $0.25 \%$ acetic anhydride in $0.1 \mathrm{M} \mathrm{TEA}$. POMC ${ }^{35} \mathrm{~S}$ labeled riboprobe was generated from cDNA templates as described previously (Cheung et al., 1997; Elias et al., 1999). cRNA probes (POMC 
Table 1. Distribution of Fos-IR and insulinR in POMC neurons of the retrochiasmatic area and the arcuate nucleus

\begin{tabular}{|c|c|c|c|c|c|c|}
\hline Region & POMC cells & $\begin{array}{l}\text { Double } \\
\text { POMC/Fos }\end{array}$ & $\begin{array}{l}\text { Percentage of double } \\
\text { POMC/Fos }\end{array}$ & $\beta$-endorphin cells & Double $\beta$-endorphin/IR & $\begin{array}{l}\text { Percentage of double } \\
\beta \text {-endorphin/IR }\end{array}$ \\
\hline \multirow[t]{2}{*}{ RCA } & $17.0 \pm 3.2$ & $1.3 \pm 0.3^{a}$ & $9.4 \pm 4.4^{a}$ & \multirow[t]{2}{*}{$15.7 \pm 2.0$} & \multirow[t]{2}{*}{$4.3 \pm 0.8$} & \multirow[t]{2}{*}{$27.9 \pm 3.8$} \\
\hline & $13.4 \pm 1.8$ & $4.4 \pm 0.7^{b}$ & $33.6 \pm 3.0^{b}$ & & & \\
\hline \multirow[t]{2}{*}{ Arc1 } & $37.3 \pm 4.3$ & $0.7 \pm 0.6^{a}$ & $1.7 \pm 0.9^{a}$ & \multirow[t]{2}{*}{$43.0 \pm 3.8$} & \multirow[t]{2}{*}{$11.3 \pm 0.9$} & \multirow[t]{2}{*}{$26.4 \pm 0.6$} \\
\hline & $41.0 \pm 6.8$ & $10.4 \pm 2.0^{b}$ & $25.0 \pm 4.5^{b}$ & & & \\
\hline \multirow[t]{2}{*}{ Arc2 } & $16.6 \pm 2.0$ & $1.0 \pm 0.6^{a}$ & $5.3 \pm 2.9^{a}$ & \multirow[t]{2}{*}{$17.0 \pm 1.5$} & \multirow[t]{2}{*}{$6.3 \pm 1.5$} & \multirow[t]{2}{*}{$36.4 \pm 4.4$} \\
\hline & $22.0 \pm 5.5$ & $4.2 \pm 0.8^{b}$ & $19.3 \pm 2.6^{b}$ & & & \\
\hline \multirow[t]{2}{*}{ Arc3 } & $7.3 \pm 1.5$ & $0.0 \pm 0.0^{a}$ & $0.0 \pm 0.0^{a}$ & \multirow[t]{2}{*}{$5.0 \pm 3.0$} & \multirow[t]{2}{*}{$0.6 \pm 0.6$} & \multirow[t]{2}{*}{$6.1 \pm 4.7$} \\
\hline & $6.8 \pm 3.5$ & $0.2 \pm 0.2^{b}$ & $3.3 \pm 3.3^{b}$ & & & \\
\hline
\end{tabular}

Values represent estimates of mean counts of cells \pm SEM. The mice received an injection of either leptin $(n=5)$ or PFS $(n=3)$ intraperitoneally. We used adjacent sections of the same mice for POMC or insulinR in situ hybridization ${ }^{35}$ S riboprobes). IR, insulinR; Arc1, arcuate nucleus of the hypothalamus, rostral level; Arc2, arcuate nucleus of the hypothalamus, intermediate level; Arc3, arcuate nucleus of the hypothalamus, caudal level; RCA, retrochiasmatic area. ${ }^{a}$ Saline.

${ }^{b}$ Leptin.

and insulinR) were diluted to $10^{6} \mathrm{cpm} / \mathrm{ml}$ in hybridization buffer as described and applied to series of hypothalamic sections. Sections were hybridized overnight at $50^{\circ} \mathrm{C}$. The following day, tissue was rinsed four times in $4 \times$ sodium chloride/sodium citrate (SSC) and incubated in $0.002 \%$ RNase A (Roche Applied Bioscience) diluted in $0.5 \mathrm{M} \mathrm{NaCl}, 10$ $\mathrm{mm}$ Tris- $\mathrm{HCl}, \mathrm{pH} 8.0$, and $1 \mathrm{~mm}$ EDTA for $30 \mathrm{~min}$ at $37^{\circ} \mathrm{C}$. Sections were submitted to stringency wash in $0.1 \times \mathrm{SSC}$ for $60 \mathrm{~min}$ at $55^{\circ} \mathrm{C}$. Series of sections of mice treated with leptin or saline were incubated in anti-Fos antisera (1:20,000, Calbiochem) and processed for standard immunoperoxidase reaction using $\mathrm{ABC}$ kit (Vector). Series of sections from male wild-type C57BL/ 6 mice were incubated in anti- $\beta$-endorphin antisera (1:10,000, Phoenix Pharmaceutical) and processed for standard immunoperoxidase reaction using ABC kit (Vector). Tissue was mounted onto SuperFrost Plus slides (Fisher Sci) and dehydrated in increasing concentrations of ethanol. After air drying, slides were placed in $\mathrm{x}$-ray film cassettes with BMR-2 film (Kodak) for 1-3 d. Slides were then dipped in NTB2 photographic emulsion (Kodak), dried, and stored in desiccantcontaining, foil-wrapped slide boxes at $4^{\circ} \mathrm{C}$ for $1-3$ weeks. Slides were developed with D-19 developer, dehydrated in increasing concentration of ethanol, cleared in xylenes, and coverslipped with Permaslip. Sections were analyzed with a Zeiss Axioplan microscope.

Estimates of cell counts. In all procedures, the estimates of cell counts were done as previously described (Elias et al., 1999). Briefly, the relative number of neurons containing leptin-induced Fos-IR and POMC mRNAs was counted in the retrochiasmatic area (RCA) and arcuate nucleus of the hypothalamus (Arc) using $10 \times$ and $20 \times$ objectives. Similarly, the relative number of cells containing B-endorphin that also contained insulinR mRNA in the RCA and Arc was also counted. Silver grains above background in that diameter for POMC or insulin mRNAs were considered double-labeled cells (Fos + POMC or B-endorphin + insulinR). The data were not corrected for double counting because the objects that we were counting did not change in size, and section thickness did not vary between groups; any systematic error should be identical for all groups. Hence, as all double-label studies are inherently qualitative, our results are meant to provide relative data, but are not meant to be accurate estimates of absolute cell counts. Differences between leptin- and PFS-treated groups were analyzed by Student's $t$ test.

Production of photomicrographs. Photomicrographs were produced by capturing images with a digital camera (Axiocam, Zeiss) mounted directly on the microscope (Zeiss Axioplan). Image editing software (Adobe Photoshop) was used to combine photomicrographs into plates. Only the sharpness, contrast, and brightness were adjusted. Cytoarchitectonic details were added by using a camera lucida.

\section{Results}

\section{Leptin-induced Fos-IR and insulin receptor mRNA in POMC neurons}

We first identified leptin and insulin-responsive POMC cells within the mouse mediobasal hypothalamus. The protein Fos has been used as a general marker for cellular activation (Hoffman et al., 1993; Hoffman and Lyo, 2002). Moreover, Fos is a useful marker for measuring leptin activation in POMC neurons (Elias et al., 1999). To assess the identity of neurons expressing Fos after leptin administration, we examined leptin- $(n=5)$ and PFS$(n=3)$ treated mice perfused $2 \mathrm{~h}$ after treatment. Hypothalamic sections were processed for in situ hybridization histochemistry (ISHH) for POMC mRNAs followed by Fos immunohistochemistry. Similar to what has been described in rats, we found that $34 \%(t(\mathrm{df})=6, p<0.05$ compared with PFS-treated mice, Student's $t$ test) of POMC cells in the RCA and up to $25 \%(t(\mathrm{df})=6$, $p<0.05$ compared with PFS-treated mice, Student's $t$ test) in the Arc express leptin-induced Fos-IR (Fig. 1A). Control (PFS) mice exhibited very little Fos-IR in POMC neurons in the RCA/Arc $(4.1 \pm 1.6 \%, n=3)$ (Table 1). Additionally, we also noted a rostrocaudal as well as a mediolateral topographic distribution of POMC cells that express leptin-induced Fos-IR (Fig. $1 B-E$ ). Specifically, rostral sections exhibited a higher percentage of leptinactivated cells in the lateral regions toward the optic tracts, while more caudal levels showed leptin-responsive cells bordering the third ventricle. We next investigated whether POMC cells also expressed insulin receptor. Hypothalamic sections were processed for ISHH for insulin receptor followed by B-endorphin immunohistochemistry (Fig. $1 F$ ). We found that $\sim 28 \%$ POMC cells in the RCA and up to $36 \%$ in the Arc express insulin receptor (Table 1). Similar to the leptin responsive neurons we observed an anatomic pattern of insulin receptor expression by POMC cells. However, this was a rostrocaudal and mediolateral pattern in which insulin receptor colocalization was adjacent to the third ventricle in rostral sections and less colocalized around the ventricle at more caudal levels (Fig. $1 G-J$ ). These histological data suggested that leptin and insulin receptors may be in distinct subpopulations of POMC cells.

\section{Acute effects of leptin and insulin in POMC neurons}

To further determine leptin and insulin responsive POMC cells, whole-cell patch-clamp recordings were performed on 117 POMC-GFP neurons anatomically confined to either the RCA or the arcuate nucleus from 41 mice (Fig. 2). When $\mathrm{K}^{+}$was used as the major cation in the recording pipette, POMC neurons $(n=$ 117 ) had a resting membrane potential of $-53.4 \pm 0.6 \mathrm{mV}$. Neurons were dialyzed with Alexa Fluor 594 hydrazide dye throughout the recording (Fig. 2C). Recorded neurons were identified as GFP-labeled POMC neurons via real-time visualization under fluorescence microscopy and via post hoc identification of Alexa Fluor dye (Fig. 2D,E). In current clamp mode, insulin (50 nм) resulted in a hyperpolarization from rest in 10 of 40 POMC-GFP neurons $(25 \%,-6.3 \pm 0.6 \mathrm{mV} ; n=10)$ (Fig. $2 F)$. The remaining cells were unaffected in response to insulin $(75 \%,-0.6 \pm 0.7 \mathrm{mV})$ 


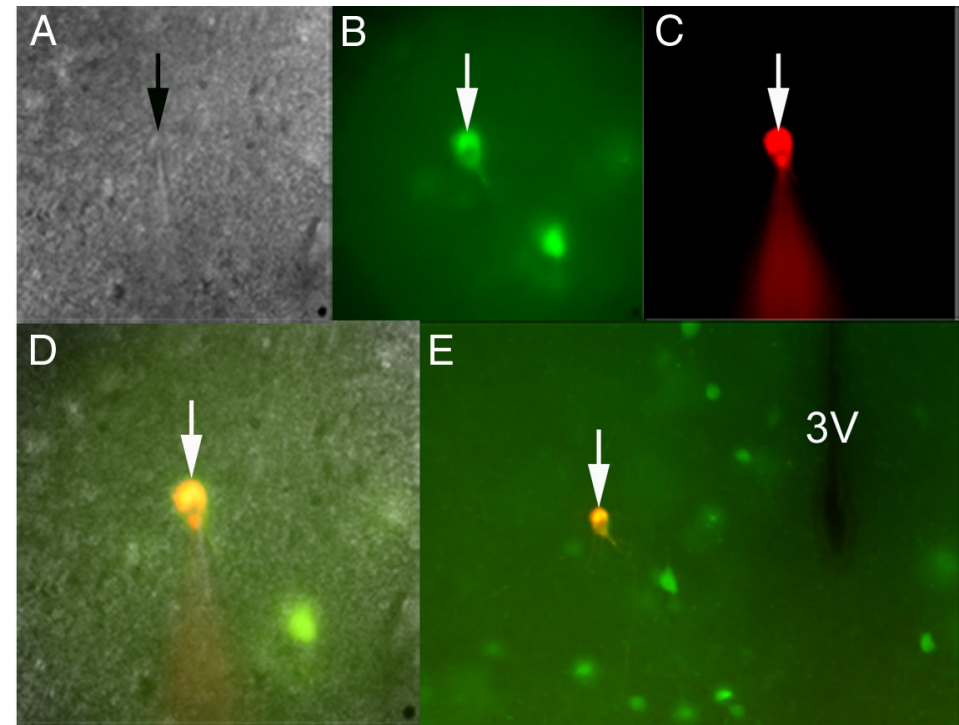

$\mathrm{F}$

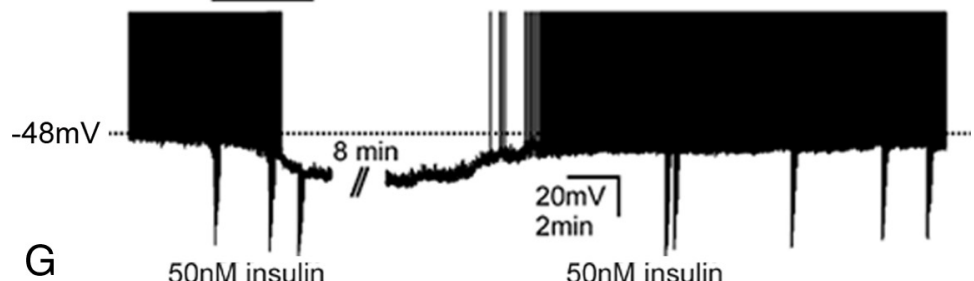

G $50 \mathrm{nM}$ insulin $50 \mathrm{nM}$ insulin

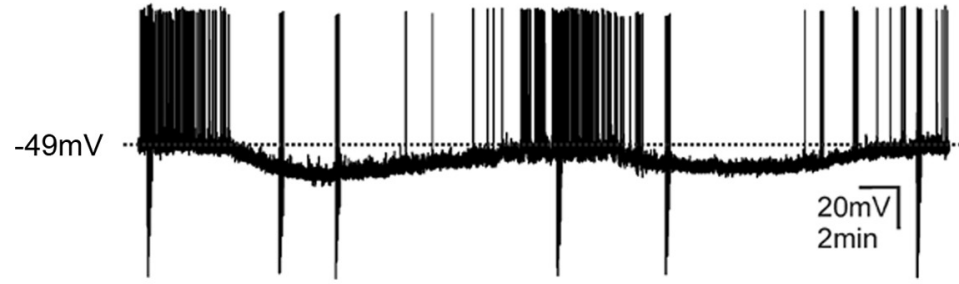

H 100nM leptin

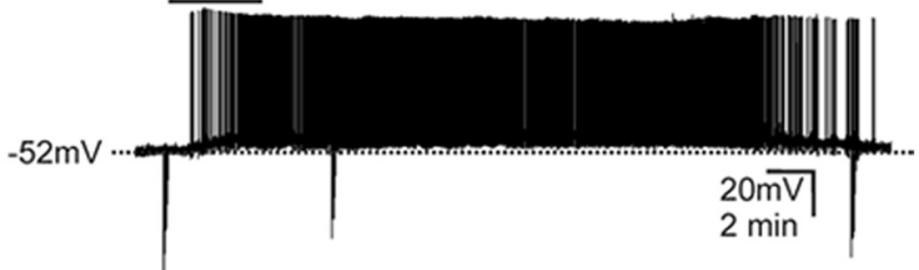

Figure 2. Identification of insulin inhibited and leptin excited POMC neurons in the rectrochiasmatic area and the arcuate nucleus for whole-cell patch-clamp recordings. $A$, Brightfield illumination of POMC-GFP neuron during acquisition of a whole-cell recording (arrow indicates the targeted cell). $\boldsymbol{B}$, The same neuron under fluorescent (FITC) illumination. $\boldsymbol{C}$, Image shows the complete dialysis of Alexafluor-594 from the intracellular pipette at the end of the recording. $\boldsymbol{D}$, Image illustrates colocalization of Alexafluor-594 with the GFP expression in the same POMC-GFP neuron. E, Post hoc identification of recorded neuron within the RCA in relation to third ventricle ( $3 V)$. $\boldsymbol{F}$, Current-clamp recording of cell depicted in $\boldsymbol{A}-\boldsymbol{E}$ demonstrating that insulin $(50 \mathrm{~nm})$ results in hyperpolarization of some POMC-GFP neurons. G, Current-clamp recording of a POMC-GFP neuron which hyperpolarized in response to successive application of insulin $(50 \mathrm{nM}) \cdot \boldsymbol{H}$, Current-clamp recording of a different cell demonstrating that leptin $(100 \mathrm{nM})$ results in a depolarization in some POMC-GFP neurons. Traces $(\boldsymbol{F}-\boldsymbol{H})$ depict a reversal within $20-30$ min following washout. (Downward deflections represent voltage deflections to hyperpolarizing current injections).

(Table 2). In agreement with previous reports in the mediobasal hypothalamus, the insulin-induced inhibition of POMC neurons was completely reversible in most of the cells recorded $(n=9)$, while only one cell did not recover before the recording was lost (Spanswick et al., 2000; Hill et al., 2008). Moreover, the insulin-induced hyperpolarization was repeatable in subsequent applications in 5 neurons tested (Fig. 2G). Insulin-inhibited POMC cells were largely confined to the rostromedial aspect of the RCA and Arc (Fig. 3). We did not observe any cells which were inhibited by insulin in the most caudal level of the Arc which is in agreement with our histology suggesting a sparse distribution of insulin receptor in POMC cells at this caudal level. Leptin (100 nM) caused a depolarization from rest in 16 of 46 POMC-GFP neurons $(35 \%,+7.6 \pm 0.9 \mathrm{mV} ; n=16)$ (Fig. $2 H$ ). Although one cell was hyperpolarized in response to leptin, the remaining 29 neurons remained unchanged (63\%, $0.9 \pm 0.8 \mathrm{mV}$ ) (Table 2). Similar to reports describing acute leptin activation in regions of the hypothalamus (Cowley et al., 2001; Dhillon et al., 2006; Claret et al., 2007; Hill et al., 2008), the depolarization was long lasting in most of the cells such that the depolarization did not reverse during the recording ( $n=$ 14). However, 2 cells completely recovered membrane potential within 20-30 min after washout. Post hoc identification of leptin-excited POMC cells mirrored histological data obtained in that there appeared to be a rostrocaudal and mediolateral distribution to the responses (Fig. 3, Table 2).

\section{Acute leptin and insulin responses in distinct populations of POMC cells} To further delineate whether POMC cells could respond to both insulin and leptin, identified POMC cells were next assessed for effects on membrane potential following successive application of both peptides. Similar to previous reports that investigated the acute effects of insulin or peptides that activate a Katp conductance in the hypothalamus or brainstem, we found the acute insulin-induced inhibition of POMC cells readily reversible (Spanswick et al., 2000; Williams and Smith, 2006; Williams et al., 2007; Hill et al., 2008) and repeatable in subsequent applications (Fig. 2G). Therefore, the membrane potential of identified POMC cells was first monitored in the presence of insulin. Following washout of insulin, changes in cellular activity were then examined in the presence of leptin. Similar to our previous experiments and prior reports, insulin (50 nM) hyperpolarized 10 of 31 POMC neurons (32\%; $-6.0 \pm 0.3$ $\mathrm{mV} ; n=10$ ) (Fig. 4A). After washout of the insulin-induced hyperpolarization, subsequent application of leptin (100 nM) failed to result in a change of membrane potential in all neurons which previously hyperpolarized in response to insulin $(0.2 \pm 0.9 \mathrm{mV}, n=10)$. The remaining 21 cells were unre- 
Table 2. Distribution of leptin-activated and insulin-inhibited POMC neurons in the retrochiasmatic area and the arcuate nucleus

\begin{tabular}{|c|c|c|c|c|c|c|}
\hline Region & Recorded cells & Leptin-activated cells & Percentage of leptin-activated cells & Recorded cells & Insulin-inhibited cells & Percentage of insulin-inhibited cells \\
\hline $\mathrm{RCA}$ & 17 & 4 & 23.5 & 19 & 7 & 36.8 \\
\hline Arc1 & 10 & 2 & 20.0 & 7 & 2 & 25.0 \\
\hline Arc2 & 12 & 8 & 66.7 & 9 & 1 & 11.1 \\
\hline Arc3 & 7 & 2 & 28.6 & 5 & 0 & 0.0 \\
\hline
\end{tabular}

Values represent the number and percentage of POMC neurons (RCA and Arc) that were targeted and either depolarized or hyperpolarized in the presence of leptin and insulin, or remained unchanged. Arc 1 , Arcuate nucleus of the hypothalamus, rostral level; Arc2, arcuate nucleus of the hypothalamus, intermediate level; Arc3, arcuate nucleus of the hypothalamus, caudal level; RCA, retrochiasmatic area.

sponsive to a single application of insu$\operatorname{lin}(-0.8 \pm 0.4 \mathrm{mV}, n=21)$. However, subsequent application of leptin (100 $\mathrm{nM})$ resulted in a depolarization in 7 of these 21 POMC cells $(6.8 \pm 1.9 \mathrm{mV}, n=$ 7 ) (Fig. 4B). The remaining 14 cells were unresponsive to leptin and insulin. Plotting the location of POMC neurons that responded to either insulin or leptin results in a rostrocaudal division of acute leptin and insulin responses, which mirrors that describing leptin-induced Fos-IR and insulinR in POMC cells (Fig. $4 C, D)$.

\section{Discussion}

There has been an increasing interest in understanding the actions of insulin and leptin in the CNS. Intense investigation showed that insulin and leptin converge in many of the same brain areas to reduce food intake and modify glucose and energy homeostasis (Carvalheira et al., 2005; Morton et al., 2005; Xu et al., 2005). Moreover, both peptides have been shown to have opposite actions on neurons within the mediobasal hypothalamus (Claret et al., 2007; Hill et al., 2008). Interestingly, the acute effects of insulin and leptin require the enzyme PI3-kinase in the arcuate nucleus (Mirshamsi et al., 2004; Hill et al., 2008). Naturally, this raises the question of how can two peptides effect cells disparately via the same intracellular mechanism.

\section{Divergent leptin and insulin signaling at the level of the POMC cell}

Several reports indicate that as few as $30 \%$ or as many as $90 \%$ of POMC cells in the arcuate nucleus were excited by leptin (Cowley et al., 2001; Choudhury et al., 2005; Claret et al., 2007; Hill et al., 2008). Similarly, previous studies have reported $50 \%$ to $80 \%$ of POMC cells are hyperpolarized in response to insulin (Choudhury et al., 2005; Claret et al., 2007; Hill et al., 2008). However reports have not directly assessed the differences between leptin-activated and insulin-inhibited POMC cells. Here we report that leptin resulted in a depolarization in $35 \%$ of all POMC neurons from the retrochiasmatic area and arcuate nucleus of the mediobasal hypothalamus. The leptin-induced excitation was observed throughout the rostrocaudal levels of the RCA and Arc (from $-0.94 \mathrm{~mm}$ to $-2.30 \mathrm{~mm}$ bregma). However, there was a higher percentage of leptin-excited POMC cells in the lateral division of the RCA and medial group of POMC cells in the Arc, such that $40-70 \%$ of POMC cells were excited by leptin in these topographic regions. Moreover, plotting the leptin-induced activation as measured by Fos-IR resulted in a neuroanatomical pattern analogous to the leptin effects observed on acute cellular excitation. On the other hand, insulin-inhibited POMC cells (25\%) were largely localized to the medial divisions of the RCA and rostromedial areas of the arcuate nucleus which is in agreement with the observed distribution of insulin receptor. Together, these data suggest that the variability of leptin-activated and insulin-inhibited POMC neurons previously reported may have been dependent upon the rostrocaudal and/or mediolateral level at which cells were identified and/or targeted. In support of this, we found it noteworthy that studies which report a large percentage of insulin-inhibited arcuate POMC cells also suggest a lower percentage of leptin-excited cells and vice versa (Plum et al., 2006; Claret et al., 2007; Hill et al., 2008). Thus, the distribution of insulin receptor and acute effects of insulin in POMC cells directly contrast with the description of acute leptin-induced activation of POMC cells and suggests a segregation of insulin and leptin responses in arcuate POMC cells. One technical consideration is that Fos-IR has been considered a measure of cellular activation largely out of association (Sagar et al., 1988; Hoffman et al., 1993; Luckman et al., 1994; Elias et al., 2000). Here, we show that $\sim 30 \%$ of POMC cells in the mouse express Fos protein in response to leptin. Similarly, $\sim 30 \%$ of POMC cells are depolarized in response to leptin. Moreover, the topographic distribution of Fos-IR and cellular activation in response to leptin mirror one another. Granted this is not a direct assessment of Fos-IR expression in activated cells, but these data extend previous observations that at least in the arcuate POMC cells Fos-IR directly correlates with leptin-induced cellular activation. 


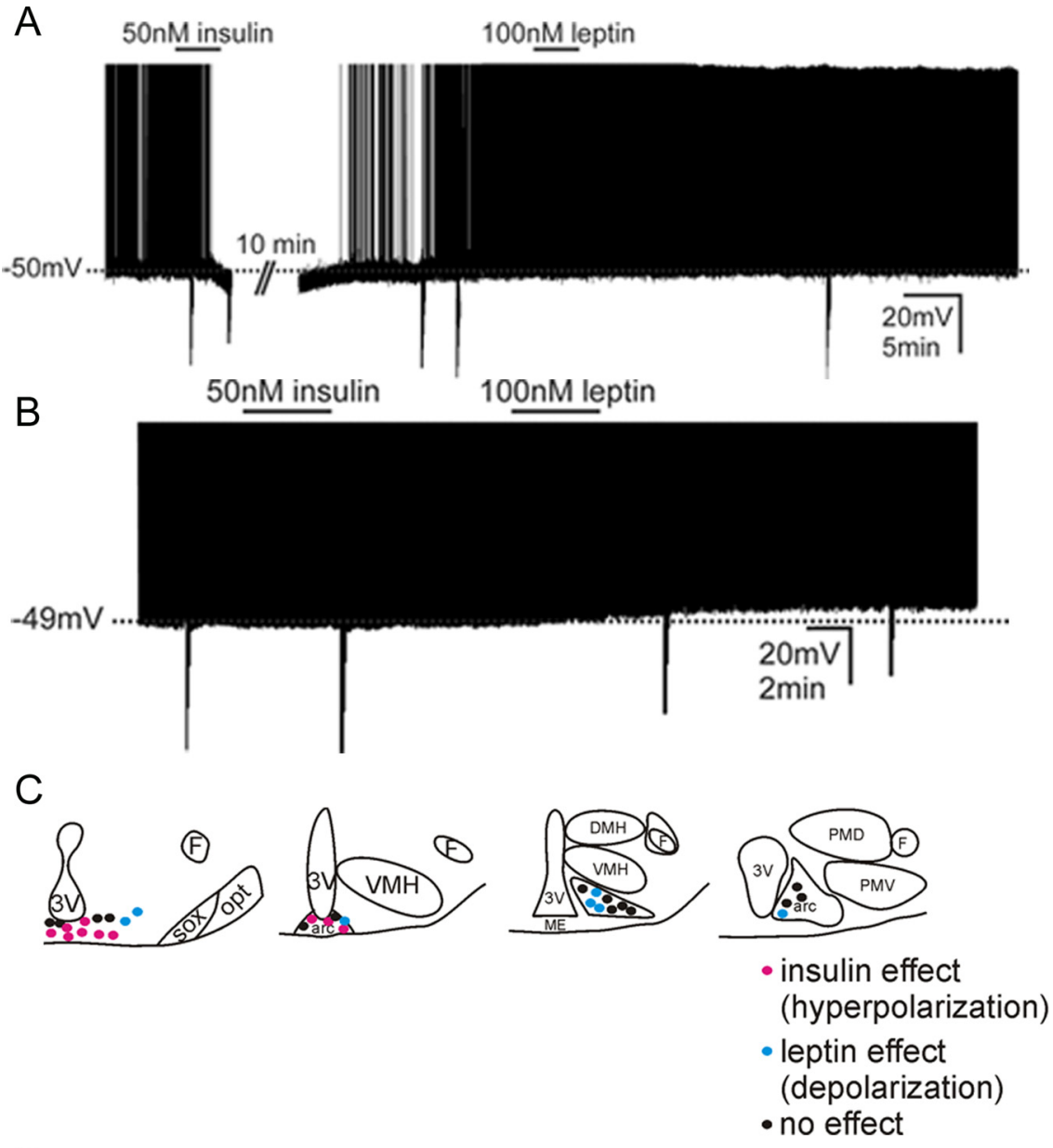

D

\begin{tabular}{|c|c|c|c|c|}
\hline Region & Recorded cells & Leptin activated cells & Percent leptin-activated \\
\hline RCA & 13 & 2 & 15.4 \\
Arc1 & 6 & 1 & 16.7 \\
Arc2 & 8 & 3 & 37.5 \\
Arc3 & 4 & \multicolumn{2}{|c|}{1} & 25.0 \\
\hline Region & Insulin inhibited cells & Percent insulin-inhibited & Unresponsive cells & Percent unresponsive \\
\hline RCA & 7 & 53.8 & 5 & 38.5 \\
Arc1 & 3 & 50.0 & 2 & 33.3 \\
Arc2 & 0 & 0.0 & 5 & 62.5 \\
Arc3 & 0 & 0.0 & 3 & 75.0 \\
\hline
\end{tabular}

Figure 4. Leptin and insulin modify the acute cellular activity of disparate POMC-GFP neurons in the retrochiasmatic area and the arcuate nucleus. $A$, Current-clamp recording shows RCA and arcuate POMC-GFP cells that hyperpolarized in response to insulin fail to respond to leptin. $\boldsymbol{B}$, Current-clamp trace illustrates that RCA and arcuate POMC-GFP cells that depolarized in response to leptin fail to hyperpolarize in response to insulin. (Downward deflections represent voltage deflections to hyperpolarizing current injections) C, Representative map of leptin and insulin responses in the RCA and arcuate nucleus of the hypothalamus. D, Table of responses observed from POMC cells in the presence of insulin followed by leptin.

It is important to note that both insulin and leptin are capable of activating intracellular signaling cascades which regulate gene transcription independent of changes in cellular activity (Bates et al., 2003; Xu et al., 2007; Fukuda et al., 2008; Hill et al., 2008). Thus, failure of a POMC neuron to acutely modify cellular activity in response to leptin or insulin does not exclude the possibility that either peptide may bind to its cognate receptor and activate signaling cascades within the POMC neuron examined. Moreover, a recent report suggested that insulin could reverse a leptin-induced depolarization of POMC neurons (Al-Qassab et al., 2009). However, this activity was found in only a small number of neurons, supportive of a segregation of leptin and insulin effects. Taken with our data, we suggest that many of the POMC neurons that are acutely activated by leptin are independent of acute inhibition by insulin and vice versa.

\section{Model of leptin and insulin action in arcuate POMC cells}

The arcuate POMC cell population has largely been considered a homogeneous cell group. However, others and we have previously shown that POMC cells have varying projection patterns (Swanson and Kuypers, 1980; Baker and Herkenham, 1995; Elias et al., 1998, 1999). In rats, neurons of the RCA which express POMC/CART primarily project caudally to autonomic areas including the dorsal vagal complex and the intermediolateral cell column (IML) (Swanson and Kuypers, 1980; Elias et al., 1998; Zheng et al., 2005). On the other hand, more caudal POMC cells project largely to hypothalamic centers like the paraventricular nucleus (PVN) and the lateral hypothalamic area (LHA) (Baker and Herkenham, 1995; Elias et al., 1999). Thus, the distribution of leptin and insulin responsive POMC cells is a likely influence for the effects of these peptides on autonomic function.

Recently, it was shown that selective deletion of insulin receptors in the POMC cells has little effect on energy balance which may be attributed to the differential expression of insulin receptors in POMC cells and the differing projection patterns of these neurons (Könner et al., 2007). The current study supports a role of insulin in modifying autonomic activity rather than food intake via POMC neurons (Könner et al., 2007; Hill et al., 2010). Perhaps the topography of the leptinactivated cells is less surprising, given the involvement of LHA and PVN melocortin-4 receptors in the acute effects of leptin on energy balance. Since the downstream targets of the cells modulated by either leptin or insulin will greatly influence possible metabolic phenotypes, future studies should consider whether these POMC subpopulations are divided not only in responsiveness to selected peptides, but also in anatomical projections, and ultimately how this may influence glucose and energy homeostasis.

In conclusion, we recently assessed the effect of suppressing $\mathrm{PI} 3 \mathrm{~K}$ in POMC neurons and found that PI3K signaling was required for the acute effects of leptin to activate POMC neurons (Hill et al., 2008). Additionally, POMC neuronal inhibition in response to insulin was also PI3K dependent. Our current study showed both histological and electrophysiological evidence that details an action of leptin and insulin in disparate subgroups of arcuate POMC cells. These data extend and reconcile findings demonstrating that insulin and leptin differentially affects Arc POMC neurons via the same intracellular cascade. 


\section{References}

Ahima RS, Prabakaran D, Mantzoros C, Qu D, Lowell B, Maratos-Flier E, Flier JS (1996) Role of leptin in the neuroendocrine response to fasting. Nature 382:250-252.

Al-Qassab H, Smith MA, Irvine EE, Guillermet-Guibert J, Claret M, Choudhury AI, Selman C, Piipari K, Clements M, Lingard S, Chandarana K, Bell JD, Barsh GS, Smith AJ, Batterham RL, Ashford ML, Vanhaesebroeck B, Withers DJ (2009) Dominant role of the p110beta isoform of PI3K over p110alpha in energy homeostasis regulation by POMC and AgRP neurons. Cell Metab 10:343-354.

Baker RA, Herkenham M (1995) Arcuate nucleus neurons that project to the hypothalamic paraventricular nucleus: neuropeptidergic identity and consequences of adrenalectomy on mRNA levels in the rat. J Comp Neurol 358:518-530.

Balthasar N, Coppari R, McMinn J, Liu SM, Lee CE, Tang V, Kenny CD, McGovern RA, Chua SC Jr, Elmquist JK, Lowell BB (2004) Leptin receptor signaling in POMC neurons is required for normal body weight homeostasis. Neuron 42:983-991.

Bates SH, Stearns WH, Dundon TA, Schubert M, Tso AW, Wang Y, Banks AS, Lavery HJ, Haq AK, Maratos-Flier E, Neel BG, Schwartz MW, Myers MG Jr (2003) STAT3 signalling is required for leptin regulation of energy balance but not reproduction. Nature 421:856-859.

Carvalheira JB, Torsoni MA, Ueno M, Amaral ME, Araújo EP, Velloso LA, Gontijo JA, Saad MJ (2005) Cross-talk between the insulin and leptin signaling systems in rat hypothalamus. Obes Res 13:48-57.

Cheung CC, Clifton DK, Steiner RA (1997) Proopiomelanocortin neurons are direct targets for leptin in the hypothalamus. Endocrinology 138:4489-4492.

Choudhury AI, Heffron H, Smith MA, Al-Qassab H, Xu AW, Selman C, Simmgen M, Clements M, Claret M, Maccoll G, Bedford DC, Hisadome K, Diakonov I, Moosajee V, Bell JD, Speakman JR, Batterham RL, Barsh GS, Ashford ML, Withers DJ (2005) The role of insulin receptor substrate 2 in hypothalamic and beta cell function. J Clin Invest 115:940-950.

Claret M, Smith MA, Batterham RL, Selman C, Choudhury AI, Fryer LG, Clements M, Al-Qassab H, Heffron H, Xu AW, Speakman JR, Barsh GS, Viollet B, Vaulont S, Ashford ML, Carling D, Withers DJ (2007) AMPK is essential for energy homeostasis regulation and glucose sensing by POMC and AgRP neurons. J Clin Invest 117:2325-2336.

Cohen P, Zhao C, Cai X, Montez JM, Rohani SC, Feinstein P, Mombaerts P, Friedman JM (2001) Selective deletion of leptin receptor in neurons leads to obesity. J Clin Invest 108:1113-1121.

Cowley MA, Smart JL, Rubinstein M, Cerdán MG, Diano S, Horvath TL, Cone RD, Low MJ (2001) Leptin activates anorexigenic POMC neurons through a neural network in the arcuate nucleus. Nature 411:480-484.

Dhillon H, Zigman JM, Ye C, Lee CE, McGovern RA, Tang V, Kenny CD, Christiansen LM, White RD, Edelstein EA, Coppari R, Balthasar N, Cowley MA, Chua S Jr, Elmquist JK, Lowell BB (2006) Leptin directly activates SF1 neurons in the $\mathrm{VMH}$, and this action by leptin is required for normal body-weight homeostasis. Neuron 49:191-203.

Elias CF, Lee C, Kelly J, Aschkenasi C, Ahima RS, Couceyro PR, Kuhar MJ, Saper CB, Elmquist JK (1998) Leptin activates hypothalamic CART neurons projecting to the spinal cord. Neuron 21:1375-1385.

Elias CF, Aschkenasi C, Lee C, Kelly J, Ahima RS, Bjorbaek C, Flier JS, Saper CB, Elmquist JK (1999) Leptin differentially regulates NPY and POMC neurons projecting to the lateral hypothalamic area. Neuron 23:775-786.

Elias CF, Kelly JF, Lee CE, Ahima RS, Drucker DJ, Saper CB, Elmquist JK (2000) Chemical characterization of leptin-activated neurons in the rat brain. J Comp Neurol 423:261-281.

Fukuda M, Jones JE, Olson D, Hill J, Lee CE, Gautron L, Choi M, Zigman JM, Lowell BB, Elmquist JK (2008) Monitoring FoxO1 localization in chemically identified neurons. J Neurosci 28:13640-13648.

Halaas JL, Gajiwala KS, Maffei M, Cohen SL, Chait BT, Rabinowitz D, Lallone RL, Burley SK, Friedman JM (1995) Weight-reducing effects of the plasma protein encoded by the obese gene. Science 269:543-546.

Hill JW, Williams KW, Ye C, Luo J, Balthasar N, Coppari R, Cowley MA, Cantley LC, Lowell BB, Elmquist JK (2008) Acute effects of leptin require PI3K signaling in hypothalamic proopiomelanocortin neurons in mice. J Clin Invest 118:1796-1805.

Hill JW, Elias CF, Fukuda M, Williams KW, Berglund ED, Holland WL, Cho
Y, Chuang J, Xu Y, Choi M, Lauzon D, Lee CE, Coppari R, Richardson JA, Zigman JM, Chua S, Scherer PE, Lowell BB, Brüning JC, Elmquist JK (2010) Direct insulin and leptin action in pro-opiomelanocortin neurons is required for normal glucose homeostasis and fertility. Cell Metabolism, in press.

Hoffman GE, Lyo D (2002) Anatomical markers of activity in neuroendocrine systems: are we all 'fos-ed out'? J Neuroendocrinol 14:259-268.

Hoffman GE, Smith MS, Verbalis JG (1993) c-Fos and related immediate early gene products as markers of activity in neuroendocrine systems. Front Neuroendocrinol 14:173-213.

Kennedy GC (1953) The role of depot fat in the hypothalamic control of food intake in the rat. Proc R Soc Lond B Biol Sci 140:578-596.

Könner AC, Janoschek R, Plum L, Jordan SD, Rother E, Ma X, Xu C, Enriori P, Hampel B, Barsh GS, Kahn CR, Cowley MA, Ashcroft FM, Brüning JC (2007) Insulin action in AgRP-expressing neurons is required for suppression of hepatic glucose production. Cell Metab 5:438-449.

Liu H, Kishi T, Roseberry AG, Cai X, Lee CE, Montez JM, Friedman JM, Elmquist JK (2003) Transgenic mice expressing green fluorescent protein under the control of the melanocortin-4 receptor promoter. J Neurosci 23:7143-7154.

Luckman SM, Dyball RE, Leng G (1994) Induction of c-fos expression in hypothalamic magnocellular neurons requires synaptic activation and not simply increased spike activity. J Neurosci 14:4825-4830.

Maffei M, Halaas J, Ravussin E, Pratley RE, Lee GH, Zhang Y, Fei H, Kim S, Lallone R, Ranganathan S, et al (1995) Leptin levels in human and rodent: measurement of plasma leptin and ob RNA in obese and weightreduced subjects. Nat Med 1:1155-1161.

Mirshamsi S, Laidlaw HA, Ning K, Anderson E, Burgess LA, Gray A, Sutherland C, Ashford ML (2004) Leptin and insulin stimulation of signalling pathways in arcuate nucleus neurones: PI3K dependent actin reorganization and KATP channel activation. BMC Neurosci 5:54.

Morrison CD, Morton GJ, Niswender KD, Gelling RW, Schwartz MW (2005) Leptin inhibits hypothalamic Npy and Agrp gene expression via a mechanism that requires phosphatidylinositol 3-OH-kinase signaling. Am J Physiol Endocrinol Metab 289:E1051-1057.

Morton GJ, Gelling RW, Niswender KD, Morrison CD, Rhodes CJ, Schwartz MW (2005) Leptin regulates insulin sensitivity via phosphatidylinositol3-OH kinase signaling in mediobasal hypothalamic neurons. Cell Metab 2:411-420.

Niswender KD, Morton GJ, Stearns WH, Rhodes CJ, Myers MG Jr, Schwartz MW (2001) Intracellular signalling. Key enzyme in leptin-induced anorexia. Nature 413:794-795.

Obici S, Zhang BB, Karkanias G, Rossetti L (2002) Hypothalamic insulin signaling is required for inhibition of glucose production. Nat Med 8:1376-1382.

Parton LE, Ye CP, Coppari R, Enriori PJ, Choi B, Zhang CY, Xu C, Vianna CR, Balthasar N, Lee CE, Elmquist JK, Cowley MA, Lowell BB (2007) Glucose sensing by POMC neurons regulates glucose homeostasis and is impaired in obesity. Nature 449:228-232.

Plum L, Ma X, Hampel B, Balthasar N, Coppari R, Münzberg H, Shanabrough M, Burdakov D, Rother E, Janoschek R, Alber J, Belgardt BF, Koch L, Seibler J, Schwenk F, Fekete C, Suzuki A, Mak TW, Krone W, Horvath TL, et al. (2006) Enhanced PIP3 signaling in POMC neurons causes KATP channel activation and leads to diet-sensitive obesity. J Clin Invest 116:1886-1901.

Rahmouni K, Haynes WG, Morgan DA, Mark AL (2003) Intracellular mechanisms involved in leptin regulation of sympathetic outflow. Hypertension 41:763-767.

Ramadori G, Lee CE, Bookout AL, Lee S, Williams KW, Anderson J, Elmquist JK, Coppari R (2008) Brain SIRT1: anatomical distribution and regulation by energy availability. J Neurosci 28:9989-9996.

Sagar SM, Sharp FR, Curran T (1988) Expression of c-fos protein in brain: metabolic mapping at the cellular level. Science 240:1328-1331.

Schwartz MW, Porte D Jr (2005) Diabetes, obesity, and the brain. Science 307:375-379.

Spanswick D, Smith MA, Mirshamsi S, Routh VH, Ashford ML (2000) Insulin activates ATP-sensitive $\mathrm{K}+$ channels in hypothalamic neurons of lean, but not obese rats. Nat Neurosci 3:757-758.

Spiegelman BM, Flier JS (2001) Obesity and the regulation of energy balance. Cell 104:531-543.

Swanson LW, Kuypers HG (1980) A direct projection from the ventrome- 
dial nucleus and retrochiasmatic area of the hypothalamus to the medulla and spinal cord of the rat. Neurosci Lett 17:307-312.

Vaisse C, Halaas JL, Horvath CM, Darnell JE Jr, Stoffel M, Friedman JM (1996) Leptin activation of Stat3 in the hypothalamus of wild-type and $\mathrm{ob} / \mathrm{ob}$ mice but not db/db mice. Nat Genet 14:95-97.

Williams KW, Smith BN (2006) Rapid inhibition of neural excitability in the nucleus tractus solitarii by leptin: implications for ingestive behaviour. J Physiol 573:395-412.

Williams KW, Zsombok A, Smith BN (2007) Rapid inhibition of neurons in the dorsal motor nucleus of the vagus by leptin. Endocrinology 148:1868-1881.

Woods SC, Lotter EC, McKay LD, Porte D Jr (1979) Chronic intracerebroventricular infusion of insulin reduces food intake and body weight of baboons. Nature 282:503-505.

Woods SC, Figlewicz Lattemann DP, Schwartz MW, Porte D Jr (1990) A re-assessment of the regulation of adiposity and appetite by the brain insulin system. Int J Obes 14 [Suppl 3]:69-73; discussion 74-66.

Woods SC, Chavez M, Park CR, Riedy C, Kaiyala K, Richardson RD, Figlewicz DP, Schwartz MW, Porte D Jr, Seeley RJ (1996) The evaluation of insu- lin as a metabolic signal influencing behavior via the brain. Neurosci Biobehav Rev 20:139-144.

Xu AW, Kaelin CB, Takeda K, Akira S, Schwartz MW, Barsh GS (2005) PI3K integrates the action of insulin and leptin on hypothalamic neurons. J Clin Invest 115:951-958.

Xu AW, Ste-Marie L, Kaelin CB, Barsh GS (2007) Inactivation of signal transducer and activator of transcription 3 in proopiomelanocortin (Pomc) neurons causes decreased pomc expression, mild obesity, and defects in compensatory refeeding. Endocrinology 148:72-80.

Zhang Y, Proenca R, Maffei M, Barone M, Leopold L, Friedman JM (1994) Positional cloning of the mouse obese gene and its human homologue. Nature 372:425-432.

Zhao AZ, Huan JN, Gupta S, Pal R, Sahu A (2002) A phosphatidylinositol 3-kinase phosphodiesterase 3B-cyclic AMP pathway in hypothalamic action of leptin on feeding. Nat Neurosci 5:727-728.

Zheng H, Patterson LM, Phifer CB, Berthoud HR (2005) Brain stem melanocortinergic modulation of meal size and identification of hypothalamic POMC projections. Am J Physiol Regul Integr Comp Physiol 289:R247-R258. 